ARTICLE

DOI: $10.1057 /$ s41599-018-0093-9

\title{
Experiences of care labour, gender and work for men who teach young children
}

Suzanne O'Keeffe (1) ${ }^{1}$

\begin{abstract}
This paper explores five Irish male primary teachers' daily experiences of care labour and gender in contemporary Irish schools. Taking a feminist poststructural approach, the study employs three data-collection phases using the interview as the primary method of enquiry. It employs a voice-centred relational method of data analysis, which involves four readings of data with each reading troubling the data in different ways. This paper places specific focus on three everyday phenomena: care, emotions and the body. The evolving dynamic between gender and work is discussed in terms of a socio-cultural tension that informs the experiences of men who work with young children. Overall, two major challenges are identified. First, emotions are considered as individual, internal and private responses to situations. Yet, we absorb the norms and values of our society in the form of social and cultural practices that preserve society, which bring emotions into line with the rules proposed by society. Second, teaching is considered a soft option career for men and an essentially feminised occupation rather than a masculine one. As softness is very often associated with weakness, primary teaching does not align with traditional views of masculinities that are built on rationality, individualisation and heroism. This is a further challenge for male teachers to care in schools. Overall, male teachers are required to reproduce accounts of themselves in terms of valued masculine attributes due to the historical association between women, emotionality and care.
\end{abstract}

\footnotetext{
${ }^{1}$ Reflective Pedagogy and Early Childhood Studies, Mary Immaculate College, Limerick, Ireland. Correspondence and requests for materials should be addressed to S.O. (email: suzanne.okeeffe@mic.ul.ie)
} 


\section{Introduction}

M en have historically dominated the main spheres of public life. Privileged hegemonic positions have been maintained by male-dominant ideals that have been presented and accepted for a long time. Images of tough, dominant and combative masculinity are the heart of these ideals. The prominent position of 'man' can be read as a disguise for nonmonolithic masculinities. Jaggar's (2008a, 2008b, p 4) depiction of the "culturally masculine", which depict diplomatic and military histories as 'silencing people with less social power and confidence' can be read in relation to Kimmel's (2013, p 6) depiction of men's lives as "political leaders, military heroes, scientists, writers, artists". With this in mind, caring for young children in the public sphere can come at a personal cost to many males. Whilst, Ireland's entry into the European Union in 1973 and the subsequent socio-economic modernisation that accompanied it altered what it meant to be an Irish man, it took over 40 years to manifest into tangible change. The historic Irish Marriage Equality Referendum and the election of the first openly-gay and youngest-ever Prime Minister clearly illustrate increased public awareness and acceptance of diverse masculinities. However, working against public approval is the Cartesian habit of mind that supports oppositional binaries: men and women, mind and body, and reason and emotion. This so-called Cartesian vision, Butler (1999) contends, has "conventionally produced, maintained, and rationalised" the "implicit gender hierarchy" ( $p$ 17). Dichotomous thinking such as mind/ body opposition has become representationally aligned with male and female. Man is representationally aligned with mind and woman with body. Mind is privileged and body is subordinate. The body is what the mind is not and visa-versa. Consequently, men who teach young children do not support the codes of gender-appropriate physical or emotional labour. The starting point of this paper is the belief that social practices interact with biological, cultural, historical and philosophical situations.

\section{Theory}

Gender and work. A particularly striking feature about gender and work is the creation of new understandings of gender. Gender is said to no longer matter because it has been "de-traditionalised" (Kelan, 2009, p 25) and gender, as a structuring mechanism of society, is becoming less relevant (Beck, 2000, as cited in Kelan, 2009, p 2; Castells, 2004). Wetterer (2003) refers to this as "rhetorical modernisation", whereby gender is made invisible in people's lives even as it continues to structure their lives. In other words, people negotiate understandings of gender through preferred identity as old gender knowledge continues to be combined with new gender knowledge. This evolving dynamic between gender and work has led to an assumption that work requires the cultivation of elite masculinities that are "more sensitive and reflexive..." (Haywood and Mac an Ghaill, 2013, p $67)$. There is now greater emphasis on feminised features such as empathy, patience and understanding as assets in business (Kelan, 2009, p 25). This is because emotions are considered more powerful than thought when used as "tools" for career advancement. (Ahmed, 2014). Yet, men who perform "caring" roles face special difficulties as "feminised" discourses of service and care often carry a devalued status and do not align with dominant definitions of masculinities. If men perform femininity through nurturance and care, their sexuality is called into question; if they display masculinity through emotional distance and control, their caring skills are questioned. Within contemporary society, emotions are categorised: some emotions are considered as signs of cultivation, whilst others are considered as signs of weakness (Ahmed, 2014). Emotions are, therefore, bound up with power and "the securing of social hierarchy" (Ahmed, 2014, p 4). In exploring the experiences of care labour, gender and work for men who teach young children, the following section will explore three themes that have emerged from relevant literature on the topic: care; emotions; and the body. Male participant voices are used throughout the paper to guide the reader through different forms of knowledge that inform our understandings of men who perform emotional labour. The use of participants' voices assists the reader in engaging with the text at a deeper level and in becoming more familiar with differing participant personalities.

Care: towards a definition. This paper adopts American Philosopher Nel Noddings' (1992, p 15) definition of care to be relational, not a virtue or an individual attribute. "A caring relation is... a connection or encounter between two human beings-a carer and a recipient of care". It is a way of being in relation, not a set of specific behaviours (Nodding, 1992, p 17). For many, care is synonymous with primary teaching. However, when men exhibit caring attributes at work, they are not considered compatible with dominant definitions of masculinities. Caring qualities are not deemed appropriate to the masculinised domain of management or authority. Furthermore, a caring approach to education may suggest an anti-intellectual approach. David alludes to this when he proposes that female teachers are more suited to teach young children.

David: "I think infant teaching is geared more towards females than males because I think you have to be a bit more motherly... with the infants".

David's use of the word 'motherly' illustrates how emotions become attributes of groups, which in turn get constructed as 'being' through 'feeling' (Ahmed, 2014, p 2). David's language suggests how attributes of care are gendered: being 'a bit more motherly' suggests a feminine body, which is emotional, reactive and dependent. His comment also brings us to a related gendered aspect of emotional labour, which is the belief that emotions and care are the "natural" domains of women. Cultural conviction maintains that women are biopsychologically suited to nurturing and, in practice, are trained for it. However, this belief is problematic because it assumes that emotions are something we have. Emotions are not "in" an individual. Emotions are both movement and attachment, which connect us and hold us in place. It is their regulatory force (Butler, 1993) that shapes the very surface of bodies and worlds. The power of emotions is a productive power that produces the bodies it controls (Butler, 1993, p 1). This is clearly illustrated when adult behaviours such as patting and hugging are deemed feminine until they are performed by men. Then they are marked as "conspicuous" (King, 1998, p 137). Michael clearly outlines his limited caring options based on this assumption:

Michael: "One of the girls [Teachers] here wouldn't have thought twice about giving them a hug, wouldn't have thought twice, but as a man you do think twice."

Michael's words can be read in relation to Ahmed's (2014) belief that we are shaped by, and take the shape of, contact with others. Ahmed (2014, p 10) suggests that emotions create a social presence rather than a self-presence. It is through emotions, or how we respond to objects and others, that boundaries are made. Ahmed's (2014) theory build's on Butler's (1993; 1999) theory of materialisation, which suggests that emotions shape the surface of the body through the repetition of actions over time. The performativity of gender illustrates that what is taken to be an internal essence of gender is manufactured through a sustained set of acts. It is through the repetition of norms that worlds 
materialise and boundaries are produced (Butler, 1993, p 9). As a result, part of the construction of male teacher identities is an awareness of how others perceive male teachers and care (King, 1998, p 139). Within this in mind, the next section of this paper explores the links between men, bodies and work within a caring environment.

Emotional labour and masculinities. The feminised nature of caring professions such as primary teaching has likely implications for men who occupy and perform these roles. As the work of Alvesson (1998) and Lupton (2000) suggest, in "feminised" occupations, men engage in compensatory gendered practices so as to minimise any non-masculine associations and to restore a dominating position. This notion of courage and fearlessness in teaching children illustrates the benefits of dominating positions in terms of men's prestige and right to command. Second, men working in female-dominated professions often fear feminisation and stigmatisation that influences the way men carry out their job. Tim believes people question his sexuality because he is an Infant teacher but believes that he still has his 'authority' because "there is MR. in front of my name". This may be because gender "involves a specific relationship with bodies" in which "our social conduct does something with reproductive difference" (Connell and Pearse, 2015, p 11). Whilst, touch is an important way of communicating, is a basic need throughout our lives (Goldschmidt and van Meines, 2012, p 15) and can have positive effects on mind and body, most teachers, regardless of gender, steer clear of touch because of its pejorative connotations. Michael clearly illustrates this when stating that he will not hold the hand of a Second Class child.

Michael: "I would hold their hand no problem, certainly to direct a Junior Infant and a Senior Infant. First Class, I am beginning to think about it. Second Class, I won't...I would tend to a knee but I would stop at a hug...There's no way I would ever give a hug."

For many, the combination of children, men and a caring environment is considered "as outlandish to the point of being a risk" (Cameron et al. 1999, p 132, as cited in Skelton, 2001, p 158). This suggests a tension for men in caring roles and impinges on how men approach and perform emotional labour. This is a challenge for male teachers to care in schools, which is a largely unexamined concept in education (King, 1998, p 15)

Emotions: why should we try to understand emotions in teaching? Everyday language of emotion is based on the presumption of "interiority" (Ahmed, 2004, p 8). Emotions are considered as individual, internal and private responses to situations. Such a model of emotion looks inwards to "idiosyncratic" conditions (Walby et al., 2012, p 4) or to feelings that "are mine" (Ahmed, 2004, p 8). Yet, like everything else that is human, emotions are in part socially constructed, "bearing the marks" of the society that created them (Jaggar, 2008a, 2008b, p 386). We know that emotional experiences connect persons to others, both moving us and holding us in place. We absorb the norms and values of our society in the form of social and cultural practices that preserve society. Within a hierarchical society, the norms and values that predominate tend to serve the interests of the dominant groups, which in turn inform our emotional constitution in particular ways (Jaggar, 2008a, 2008b). In other words, emotions are brought into line with the rules proposed by society or by the self. Dominant values are implicit in responses taken to be precultural or acultural, hampering alternative ways of living (Jaggar, 2008a, 2008b, p 386). As Butler (1999, p 17) suggests, gender is a culturally authorised performance, "a repetition and a ritual”.
It is significant that teaching is considered a "soft option" career for men (Connell, 2008) and an essentially feminised occupation rather than a masculine one. Softness is very often defined in terms of weakness or proneness to injury (Ahmed, 2004) and is associated with all that is considered feminine, including the body. Typically, reason is associated with the mental, the public and the male, and emotion is associated with the irrational, the private and the female (Jaggar, 2008a, 2008b). To be emotional is to be "reactive rather than active, dependent rather than autonomous" (Ahmed, 2004, p 3). Therefore, emotions are always subordinate to reason and "potentially or actually subversive of knowledge" (Jaggar, 2008a, 2008b, p 378). The association of emotions to the body, or "inner" self, works to remind us that the very concept of the body has been formed in opposition to the mind or as "the chief enemy of objectivity" (Jaggar and Bordo, 1992, p 4). Doing work that involves emotions is fundamentally an "act of doing gender in the context of 'women's allegedly greater facility with emotions-the feminine capacity to console, and comfort, flatter..." (Frith and kitzinger, 1998, p 300, as cited in Mirchandani, 2008, p 265). Indeed, King (1998, p 126) notes that it is "...striking that the options for care are identical for men and women, but the choices are weighed differently based on gender". Certain behaviour is seen as appropriate for female teachers but not for male teachers. This is illustrated in David's story about holding children's hands on the yard.

David: "There was a special unit in the other school I was working in...I remember I had to bring them [the pupils] out to the yard and you have to hold hands with them and stuff but I wouldn't feel comfortable holding hands with kids. I know it's for their safety but still you wouldn't feel comfortable holding hands and people walking past the school...Whereas for a female teacher, probably, it's completely natural."

One way of reflecting on David's story is to consider a rethinking of the relationship between emotion, bodily sensations and reason. Whilst it is somewhat true that physiological disturbances characterise emotions: sweating, trembling and tears, are instinctive biological responses (Jaggar, 2008a, 2008b, p 381), emotions are not pre-social, involuntary responses. A cognitivist view, as cited in Ahmed (2004, p 5), suggests that emotions involve appraisals, judgements and attitudes shaped by memory and by histories that come before the subject. Emotion in this way is social and cultural rather than a presumption of interiority. When David refuses to hold a pupil's hands due to his unease, he has an impression of the risks associated with the encounter of a male adult and a child. This feeling of unease does not come from within but from without. The contact is shaped by past histories that are unavailable in that particular present (Ahmed, 2004, p 7), which in terms of masculinities is a wariness about possible misinterpretations of emotionality. Male teachers are constantly aware of others' attention to their maleness (Thornton, 1997, as cited in Skelton, 2001, p 127). Again, this illustrates how emotions are bound up with the securing of social hierarchy and relations of power. It also suggests why it is difficult for men to acknowledge their emotions (Mac an Ghaill, 1994, p 38).

Emotions and masculinities. Common-sense understanding considers emotions and masculinities to have little association with each other. Traditional views believe masculinities are built on rationality, individualisation and heroism. Mac an Ghaill (1994, p 38) traces the association of power and masculinities to the Enlightenment tradition, in which "reason is defined in opposition to nature, that is, our emotions, feelings and desires". 
Masculinities are defined by separation, while femininity is defined through attachment. This impacts on teaching, which can be described as an occupation that involves an "emotional style of offering the service" (Hochschild, 2012, p 5), which is part of the service itself. Daily teaching experiences involve emotions such as advising pupils, diffusing volatile situations and displaying positive/controlling negative emotions in the classroom. Hochschild (2012) describes various feeling rules for occupations. These can be seen in schools in the form of the tough principal, the drama teacher, the caring assistant. Connell (2000, p 153) notes that the "most important" feeling rules in schools are those relating to "sexuality, and the prohibition on homosexuality". These feeling rules, Connell ( $\mathrm{p}$ 153) maintains, may be particularly important in definitions of masculinities.

The body: why emphases bodies in a paper about care labour?. The body is one of the first identifiers of a male teacher's presence in a primary school. An association between the feminised environment and the male body indicates something unusual or strange in our mind's eye. This is primarily due to a taken-for-granted relationship between male bodies and masculinities. Society categorises men as active and women as passive in order to address and attempt to deal with "the chaos" which surrounds both concepts (Grosz, 2011, p 78). If we consider men's bodies and destructive work are "proof of the toughness of the work and the worker" (Connell, 1995: 36), then men who teach young children are not believed to be traditionally masculine. Additionally, feminine conduct combined with a male body "is felt to be anomalous or transgressive" (Connell, 2000, p 12). When teaching is considered a caring profession carried out in an emotional environment, recognition is given to the central role of the body. This is because we associate all that is biological and natural with the body and the feminine. As a result of lateral associations, which "link the mind / body opposition to a whole series of other oppositional (or binarized) terms, enabling them to function interchangeably..." (Grosz, 2011, p 3), the body is associated with women's social subordination. Further associations of lateral thinking include outside and inside, natural and cultural, self and other, depth and surface, and so on. The body and all associated feminine characteristics are presumed the latter and the mind and all associated masculine characteristics are considered the former. The relationship between the care labour, gender and work does not align with traditional Western reasoning.

\footnotetext{
Methods

Research methodology. This research draws on feminist poststructural enquiry to address the research question, what are male teachers' understandings of masculinities and how do they impact on their daily lives? Working together and separately, the participants and I paved the way through the terrain of masculinities in Irish primary schools; exploring established ways of thinking about care labour, gender and work that has an effect on male teachers' everyday realities. The theoretical orientations of feminism and poststructuralism, and, more specifically, the work of contemporary theorist, Butler (1999), influenced the methodological choice, data collection and analysis of this research (O'Keeffe, 2016). A feminist theoretical orientation disrupts traditional ways of knowing through its commitment to studying the "lived experiences" of gender (Pillow and Mayo, 2007, p 161). Feminism places the personal being at the centre of one's enquiry. This creates rich new meanings by highlighting concerns of boundaries, identities and speaking. Furthermore, poststructuralism facilitates a constant engagement with "the tensions and omissions" in a text (Jackson and Mazzei, 2012, p 5). A poststructural reading of data troubles the innocent idea of any term. It adheres to a suspicion that "something may be wrong with what we currently believe" (Jackson and Mazzei, 2012, p 23). As a result, poststructuralism holds the idea that no reading or writing of a life is ever complete. From this belief emerges accounts that "are playful, open-ended, and incomplete” (Denzin, 1989, p 46; Van Maanen, 2011). Together, a feminist perspective and a poststructuralist methodology critically deconstruct gendered social practice and support alternative understandings of power and subject formation. Deconstruction, in this sense, does not mean "dismantling and replacing" or "de-constructing and re-constructing" (Jackson and
}

Mazzei, 2012, p 15). It is a tool that facilitates the possibilities for the stories of each teacher to go far beyond the pages of this paper.

Ethical considerations. Ethical approval for this study was sought from, and granted by, the Research Ethics Committee (MIREC) at Mary Immaculate College, Ireland. Participants were advised of:

- The voluntary nature of participation;

- Confidentiality and anonymity;

- The purpose of the research.

Feminist ethical considerations. The attention given to relationships with participants illustrates the goals of feminist research to be "for" rather than "on" people. This suggests that research "on" a particular group is not necessarily beneficial for them. However, research "for" people fosters empowerment, gives back reports to participants to check descriptive and interpretive validity and is highly interactive. Relationship-building was an important consideration in this research and was fostered by:

- Regular and open communication before, during, and after each phase of interview;

- Inviting participants to select the most convenient time and place to meet;

- Informing participant of emerging themes;

- Offering transcripts to participants for review;

- Offering draft chapters to participants for feedback.

Research design. The design of this research consisted of 3 interconnected yet distinct rounds of interviews (O'Keeffe, 2016). The categorising of data collection into 3 phases enabled methodological self-reflection and interactive relationships to develop between researcher and researched (Hesse-Biber and Leavy, 2011; Rapley, 2011). Teachers, both male and female, were invited to participate in this research by responding to an open call for participants. The open call was in the form of an article, titled Why the decline in male primary school teachers? placed by the researcher in Ireland's largest teachers' union monthly magazine, InTouch (2014).

The American anthropologist, James P. Spradley's (1979) 'ethnographic interview' was used to guide informal interviews during Phase One. This ethnographic interview shares many features with a conversation-building format in which the researcher slowly and judiciously introduces a number of thematic and focusing questions. Grant McCracken's (1988) 'long interview' was used to guide semi-structured interviews during Phase Two and Phase Three. The long interview (1988) is set within a generous time frame and allows participants to tell their own stories in their own terms. This technique enabled emerging themes to be explored in greater detail. Phase One accumulated an average of $11 \mathrm{~h}$ recorded interview time for each participant. Phase Two and Phase Three amassed over $14 \mathrm{~h}$ of interviews. In total, the average time spent in dialogue with participants was over $25 \mathrm{~h}$.

Sample, contexts and settings. Three rounds of interviews and note-taking in total allowed each phase of the research design to mutually inform one another, building confidence in the sampling. Variables used to identify appropriate participants included age, number of years teaching experience, school setting and position held within the school. The sample size consisted of 11 male primary teachers in Phase One. This number was reduced to 7 male teachers in Phase Two and Phase Three. The reduction of participants in Phase Two through to Phase Three was due to family reasons and time commitments. The 4 teachers who did not continue to Phase Two and Phase Three of this research study remained part of the research journey. Initial findings and overall themes were forwarded to them for review and clarification throughout each phase.

Data collection. Data sources generated for the research were as follows:

- In-depth interviews;

- Fieldnotes.

- Governmental reports;

- Transcripts.

Data analysis. Data was analysed using a voice-centred relational method (Mauthner and Doucet, 1998). Voice and the power it holds has been a primary focus of the academic world in recent times (Hekman, 2005, p 1). Voice has frequently been privileged because of its perceived ability to account for the reality of the world. It has been assumed that voice 'can speak the truth of consciousness and experience' and has been considered 'almost a mirror of the soul, the essence of the self (Mazzei and Jackson, 2009, p 1). However, voice is 'one of the major issues confronting the poststructural paradigm' (Mazzei and Jackson, 2009, p 3). This is due to the assumption that voice can represent a universal, single truth. From a post-structural stance, researchers reject the notion of presenting data as if it speaks for itself, and instead seek practices that confront and twist voice, meaning, and truth (Lather, 2009, p 3). With this in mind, this method of data analysis involves four readings of data, with each reading troubling the data in different ways. 
The first reading is a reading for plot and is common to many methods of qualitative data analysis (Mauthner and Doucet, 1998, p 126; Corbin and Strauss, 2015). The second reading draws attention to "the active ' $I$ ' which is telling the story" and is one of the key features that distinguishes a voice-centred relational method from grounded theory (Mauthner and Doucet, 1998, p 130). This careful listening to the participant "creates a space" between the intra-action of "...how [he] speaks of [himself] before we speak of [him]" (Brown and Gilligan, 1992, pp 27-28). The second reading is not just about the words that are said, it is also about how we re-imagine what is said and how we imagine ourselves "as intra-actively produced in tandem" with what is said (Jackson and Mazzei, 2012, p 132). For example, Darren describes feeling restricted in offering a caring-for approach to Junior Infant pupils in his class. This is most evident in situations where young pupils are not fully toilet-trained.

Darren: "I can't change them so I would send them off to change on their own..."

The reader is brought back to personal feelings of repression and constraint. Yet, perhaps this sense of restriction is less about care and more about a loss of power. Reading intra-actively challenges the reader against "interpretation and experience" as the marker for understanding and encourages 'an intra-action that displaces and reinscribes power' (Jackson and Mazzei, 2012, p 133). The third reading in the voice-centred relational method reads for relationships, which is "particularly valuable in revealing the theoretical framework which quietly and pervasively underlines research" (Mauthner and Doucet, 1998, p 131). For example,

David: "What I would always be conscious of is being left with one or two [pupils] in the evenings at home time. I try to leave all the doors open that I can, so that if there are teachers out photocopying, at least they can hear in and listen in."

It facilitates further in-depth analysis of cultural and societal factors that may impact on the daily teaching lives of participants and their colleagues. This reading moves the data beyond the personal and places it in a context that has material consequences. Attending to how participants "experience themselves in the relational landscape of human life" (Brown and Gilligan, 1992, p 29) creates "an opening between self and other that creates a channel for discovery" ( $p 28)$. The fourth reading places the participants' accounts and experiences within broader social, political, cultural and structural contexts. This reading is especially valuable to attune to "the ways in which institutionalised restraints and cultural norms and values become moral voices" (Brown and Gilligan, 1992, p 29).

A voice-centred relational method of data analysis is concerned with the processes of reflection and decision making or the "private lives" of individuals. In line with post-structural thinking, the aim of this method of data analysis is to discover the daily realities of individuals and to make discoveries "worthy of others' attention" (Brown and Gilligan, 1992, p 23). This method does not claim that the participants are "representative of all" (Brown and Gilligan, 1992, p 23). As the transcripts were read, notes were made on the margin on content, emotions, interactions, and whatever else seemed important". The margin notes were copied onto separate sheets of paper, which were slowly organised around various categories. Thematic categories were developed as the "rummaging...of data analysis" (McCracken, 1988, p 33) continued. The categories came "from the interviewees' words" and from my understandings of their words (Chase, 1995, p 223). For each thematic entry, the participant's name was marked on top and the transcript page number was marked beside the theme. These entries provided the starting point for analysis of various topics in later interviews. Coding in this manner was "messier, trickier, less comforting" (Lather, 2010, p 80). However, it felt more authentic, "more genuine" (Brown and Gilligan, 1992, p 16) and more meaningful than something that looked attractive and organised in diagram format. Though the method is very detailed and time-consuming, it places the voices of the participants above the researcher's and incorporates the researcher's background and history into the analysis process. This allows data collection and analysis to intermingle and promotes methodological self-reflection and interactive relationships to develop between researcher and researched. Emerging themes are discussed with participants, which can yield fresh new insights. Participants are placed in a more powerful position by controlling the direction the interview takes.

\section{Findings}

Reinforcing existing stereotypes: hegemonic masculinities. A key aspect of male teachers' identity in relation to care and emotions is the performance of a public masculinity. This involves engaging in stereotypical behaviour. In order to secure respect and dignity, male teachers often adopt different styles of practice in the workplace that commonly represents forms of accepted masculinity. One practice is termed hegemony, which is the organisation of masculinities into hierarchical order. Hegemony is used to describe relationships in society's gender order. It is a pattern of practice that allows for men's dominance over other men and women. That is to say that it is both dominant and dominating. In primary schools, the concept of authority has been associated with male teachers and with hegemony. Hegemonic masculinity privileges the expression of "care-free" emotional displays "that appear natural and rational" (Gottfried, 2013, p 889). These categories include qualities such as aggression, "macho", pride, competitiveness and duty. While challenging the normative ascriptions of masculine behaviours, some teachers take up a heroic sense of masculinity, whereby they pioneer the care of young children (Haywood and Mac an Ghaill, 2013, p 108). For example, Matthew believes he is more authoritative than his female colleagues when addressing young children.

Matthew: "I think I am probably a little bit tougher on the kids...You know toughen up, grow up...some of the female teachers...they wouldn't tackle it as bluntly but I come in like a sledge hammer..."

Matthew's story demonstrates how male teachers can shift from exhibiting nurturance to exercising rational authority without appearing abrupt. The notion of courage and fearlessness in teaching children illustrates the benefits of patriarchy at school in terms of men's prestige and right to command. It also brings into question how neoliberal aims for education have reconstructed "our common sense" and "our very identity" (Apple, 2013, p 128). Matthew recalls a time the bell rang signalling the end of play-time but the children refused to stop playing and to "freeze".

Matthew: "I started roaring at the top of my voice 'Freeze! Freeze! You!

You!'... my poor colleague...said that it was great having me there because my voice would carry a hell of a lot further than hers did."

Representations of men and women have different meanings in different contexts. For example, in accounts of male violence men appear to have "little problem expressing their emotions" (Collier, 1998, p 28). This suggests a strong link between the male body and characteristics which are deemed masculine. It also suggests that teachers' awareness of other male teachers' discipline styles, which are informed by notions of masculinities, create "good" teachers. As Matthew believes from his story, the female teacher in his company felt happy that he took charge of the situation in a masculine manner through the use of his body; his powerful voice and authoritative presence in this instance.

Matthew: "...the kids as well would respond to my voice quicker than they would to the girls' voices during assembly or things because I'm louder, you know my voice is deeper, it's different, you know. They are not used to hearing that voice."

Men in feminised jobs often experience different expectations and rewards from women doing the same work (Gottfried, 2013, p 84). This notion of feminisation suggests a more complex analytical understanding that goes beyond the simpler framework of male and female employment participation rates (Haywood and Mac an Ghaill, 2003, p 27). As education is a process "operating through relationships" (Connell, 1993, p 19), care is an issue that confronts all teachers in primary schools. However, for men who wish to teach within a caring environment, the understanding of these issues can take interesting "twists and turns" (King, 1998, p 24).

Caring for young children: hegemonic masculinities, the body and sexuality. A central concern of men and masculinities is the sociology of the sexuality and the sociology of the body (Hearn and Morgan, 1990, p 10). A relationship exists between hegemonic masculinities and hetero-sexuality (Skelton, 2012). When men do not correspond to the perceptions of occupational masculinities, assumptions regarding heterosexuality are informed by "ordinary and academic discourses on sexuality" (Butler, 1999, p 21). Skelton (2012) considers that if aspirations to work with young children are feminine features, and femininity is "other" to dominant masculinity, then the sexuality of men who wish to engage in primary teaching is brought into question. Subsequently "other" forms of sexuality such as homosexuality and the fear of homophobia are frequently cited as a concern in relation to male teachers of young children (Martino and Rezai-Rashti, 2010). Interestingly, male teachers are also acutely aware that they may be considered as sexual initiators or aggressors (Weaver-Hightower, 2011). In support of this theory, Neil considers taking photographs of pupils at a school's sports event as inappropriate because he is a male teacher.

Neil: "...if we go to matches sometimes, you know, someone brings a camera and takes a team photograph. There is no way I am taking that. Absolutely no way...because I just feel as a male that someone's going to say 'He's there with a camera and he's taking photographs of children'...I don't think anyone would assume anything of a female doing it".

Furthermore, David recalls acquaintances outside of teaching who have "joked" about his male teacher status: "Oh, how long have you been a paedophile?" Similarly, Tim believes that his sexuality comes under scrutiny by others due to his infant teacher status,

Tim: "Is he gay because he's in Infants? Is his masculinity gone out the door when he becomes an Infant teacher?"

Furthermore, Darren notes society's perception of men who teach young children,

Darren: “...it can be presumed that if you are teaching at a lower level in the school or if you are teaching in primary schools that you could be gay or you could be..."

As stated in O'Keeffe (2016), public perception and related anxiety can be read in relation to Butler's (1999: xi) claim that sexuality and belief are related in a 
complex manner, which are "very often at odds with one another". Indeed, Butler (1999) contents that the first formulation of her most famous thesis, Gender Trouble, is the fear of losing one's place in the gender hierarchy ( $\mathrm{p} 11)$ due to a failure to appear in accordance with accepted gender norms ( $p$ 13).

Gendered engagements: connecting with boys. Teacher identities provide salient contexts for how pupils respond to educational institutions (Haywood and Mac an Ghaill, 2003, p 63). These are enacted through school discipline, as already discussed and through teaching styles. The themes of "machismo" and creating bonds with male pupils were evident in the stories recounted by many of the participants in this study. "When teachers (male or female) adopt more authoritarian types of discipline with male pupils ... they are helping to create the 'macho' modes of masculinity..." (Skelton, 1996, p 30). Writers argue that "a violent discipline system, particularly one locked into an educational system of academic success or failure, invites competition in 'machismo'... between the boys and male teachers" (Skelton, 1996, p 30). Vincent gives us an example of how bonds can easily be created with male pupils.

Vincent: “...talking to the fellas in the class... if you are talking about sport and you are talking about things like that...I understand those sorts of things and they understand those sorts of things...I can talk about those things..... there would be a bit of banter with them and you would feel you have a bit of a connection with them..."

Boys were a common topic of concern for male teachers. For instance, John notes "the difficulty of being male", which resonates with Vincent's earlier remarks about connecting with male pupils

John: “...boys occupying a bigger social space in the classroom whether it's for volume of conversation or distractibility or need for teacher attention or just literally physical space in the playground...that's the way it is and so the response to that, the response to a male teacher is different...perhaps it may be easier for a male teacher to get somewhere with those particular pupils...I've seen boys respond differently and perhaps a little more positively to a male interaction."

Gendered engagements with pupils illustrate how boys occupy a particular place within discourses on masculinities, "...one which places 'masculinities' as, at once, of far more significance than 'femininities"' (Skelton, 1996, p 32). Additionally, drawing attention to "macho" modes of masculinities in communal spaces such as the staffroom and public arenas provides teachers with 'kudos' (Skelton, 1996, p 31) among their colleagues.

\section{Discussion}

Care. When boundaries of public, such as the workplace, and private, such as care become blurred, male teachers adopt alternative resources to validate their masculine identities. Care may manifest in caring-for and caring-about (King, 1998, p 126). Engaging in caring-for behaviour involves listening, speaking softly, touching, hugging and providing space. Women, in general, have been expected to care in this manner, "that is, to provide tender, hands-on caregiving" (Noddings, 2006, p 229). These acts may seem "unnatural" when enacted by male teachers. When men work within an environment of care and exhibit caring and emotional attributes, "these qualities are not consonant with dominant definitions of masculinities" (Haywood and Mac an Ghaill, 2003, p 27). Indeed, motherly or caring qualities are not deemed appropriate to the masculinized domain of management or authority. On the other hand, caring-about behaviour denotes a detached form of care-giving based around encouraging academic achievement, representing pupils and generally caring from a distance as opposed to a more tactile "maternal" care. Sustaining beliefs about men and masculinities can be read in relation to the "global subordination of women to men" (Connell, 1987, p 183). Within this framework, which connects masculinities to wider social and economic forces, caring is associated with "subservience" (Noddings, 2006, p 228). Similarly, King (1998, p 126) notes the "subordinated status" of care. With this in mind, understandings of masculinities impact on what is considered as work. Alvesson and Billing (1997, p 90) contend that gendered work is "deeper than sex typing, meaning that not only is a job openly viewed as women's or men's work, but that it refers also to non-explicit meanings, unconscious fantasies and associations". As Butler (1993, p 20) contends "we have to present ourselves as bounded beings" whose identity is constituted in the public sphere. Gender, as an identity marker, is used to identify appropriate behaviour in situations

Deconstructing masculinities. Teaching involves care and emotions as much as "pure reasoning" (Connell, 1993, p 63). Caring about children as a teaching philosophy and caring for children as enactment of that philosophy are valued descriptions of primary teaching (King, 1998, p 23). Indeed, "teach the child, not the subject" is a common mantra of primary teachers. In Western culture and in our society, women usually fulfil the role of care-giver (Hekman, 2005, p 125). According to Reskin (1991, p 147) women are said to have a "natural talent" for caring and "similar work". As a result, when teaching is understood as an act of caring, men's work as caregivers "is a complex endeavour" (King, 1998, p 4). This is in part due to the fact that emotions are treated and interpreted differently when expressed by a woman or a man (Gottfried, 2013, pp 83-84). Furthermore, it is a result of the complicated ways in which gender is constructed and embedded in work norms and practices. When men work within an environment of care and exhibit caring and emotional attributes, "these qualities are not consonant with dominant definitions of masculinities" (Haywood and Mac an Ghaill, 2003, p 27). Collinson and Hearn (1996, p 1) note the "strange silence", which reflects "an embedded and taken-for-granted association, even conflation" of men with power, authority and prestige. In this case, the "remasculinization of teaching...is characterised by emotional detachment" (Haywood and Mac an Ghaill, 2003, p 64). Haywood and Mac an Ghaill are referring to what Whitehead (2002, p 51) terms "the masculinist paradigm at the heart of education" that encapsulates "competition, outcome, achievement, work ethic and performativity, as both the purpose and defining character of education" (As cited in Haywood and Mac an Ghaill, 2013, p 89). This is a challenge for male teachers to care in schools, which is a largely unexamined concept in education (King, 1998, p 15).

Addressing assumptions: empowering research designs. The fact that the number of males entering teaching is static and that male teachers within the profession feel isolated due to various forces are not neutral occurrences. They are not natural economic patterns. It is the result of cultural, economic and political conflicts, compromises and tensions that organise society (Apple, 1996). This paper recommends placing a growing appreciation on the need for research that advances a more equal world. It recommends exploring “...the links between knowledge and power" (Lather, 1991, p 19) and challenging accepted forms of knowledge or "the naturalness of social arrangements" (Lather, 1991, p 63). In other words, spaces must be forged to enact feminist research designs so that something 'other' may been seen. The most compelling aspect of feminisms' alternative approach to traditional forms of thinking is the inclusion of the historically feminine into the knowledge-building process: emotion, embodiment, interpretation and subjectivity. "Instead of viewing these aspects as contaminations or barriers to uncovering the objective truth", feminist researchers believe that human experiences and perspectives "may actually become a tool for knowledge building and rich understanding" (Hesse-Biber and Leavy, 2011, p 12). Most recently a new feminist alternative has emerged that wishes to "build meaningful conversations" (Barad, 2007, p 25) between the sciences, a traditionally masculinized sphere and the humanities, a traditionally female sphere. More clearly, it indicates the direction this conversation should take. "...there is a building consensus among feminists and critical theorists that a new approach is needed and that feminism is and should be at the forefront of that effort" (Hekman, 2005, p 68). It 
requires conducting research in a non-elitist and nonmanipulative manner where "accountability is to a research community rather than to a client or sponsor" (Lather, 2010, p 6). We all have a role to play.

\section{Conclusion}

Male- and female-dominated occupations require workers to perform different kinds of emotion work. Teachers may feel annoyance or tiredness, but are expected to be calm, caring and in control. Emotion work is, therefore, needed to bridge the gap between how one feels and how one should feel. Given the historical association between women, emotionality and care, male teachers are required to reproduce accounts of themselves in terms of attributes which commonly represent a type of accepted masculinity. With this in mind, emphasis must be placed on the gendered nature of work itself in the context of gendered processes rather than identifying the separate impact of gender on emotions. People's practices are constrained by educational institutions and their structures, which go deep into an individual's emotional life. Emotional relations may be positive or negative. "Workers in homogenous work settings" such as primary schools may do "emotion work to exert privilege and exclusion" (Mirchandani, 2008, p 272). Emotions represent an area in need of action. An adequate theory of gender requires, Connell (1987, p 91) believes, a theory of social structures or frameworks "much stronger" than role theory. In relation to shaping masculinities and femininities in the workplace, an adequate theory must call into question the relationships between men and women in terms of authority and power. Authority and power are generally easy to observe. Yet, it is often difficult to see beyond individual acts of power to a structure of power: a set of social relations that constrains social practice (Connell, 1987, p 107). Connell (1987) outlines three frameworks that structure gender relations at work. The first framework is the division of labour. The second framework is power. The third framework is emotions. Emotions cannot be considered on their own but as part of a larger pattern, a structure of power that deeply affects the daily working lives of men, as well as women.

Received: 26 August 2017 Accepted: 19 March 2018

Published online: 17 April 2018

\section{References}

Ahmed S (2004) The cultural politics of emotion. Edinburgh University Press, Edinburgh

Ahmed S (2014) The cultural politics of emotion. 2nd edn. Edinburgh University Press, Edinburgh

Alvesson M (1998) Gender relations and identity at work: a case study of masculinities and femininities in an advertising agency. Human Relations 51 (8):969-1005

Alvesson M, Due Billing Y (1997) Understanding gender and organisations. SAGE Publications, Thousand Oaks, California, London

Apple MW (2013) Can education change society? Routledge, New York

Apple MW (1996) Cultural politics and education. Teachers College Press, New York

Barad K (2007) Meeting the universe halfway. Quantum physics and the entanglement of matter and meaning. Duke University Press, Durham

Beck U (2000) The brave new world of work. Polity, Cambridge. as cited in in Kelan E, Performing Gender at Work. Palgrave MacMillan, Hampshire

Brown L, Gilligan C (1992) Meeting at the Crossroads. Ballantine Books, New York, NY

Butler J (1993) Bodies that matter: on the discursive limits of 'sex'. Routledge, New York

Butler J (1999) Gender trouble: feminism and the subversion of identity. Routledge, New York

Cameron C, Moss P, Owen C (1999) Men in the nursery. Paul Chapman, London
Castells M (2004) Das Informationszeitalter 2: Die Macht der Identität. Leske +Budrich: Opladen. as cited in Kelan E (2009) Performing gender at work. Palgrave MacMillan, Hampshire

Chase S (1995) Ambiguous Empowerment: The Work Narratives of Women School Superintendents. University of Massachusetts Press, Amherst, MA

Collier R (1998) Masculinities, crime and criminology: men, heterosexuality and the criminal(ised) other. SAGE Publications, London

Collinson DL, Hearn J (1996) Breaking the silence: on men, masculinities and managements. In: Collinson DL, Hearn J (eds) Men as managers, managers as men. critical perspectives on men, masculinities and managements. SAGE Publications, London; Thousand Oaks; New Delhi, pp 1-24

Connell RW (1987) Gender and power. Polity, Cambridge

Connell RW (1993) Schools and social justice. Temple University Press, Philadelphia

Connell RW (1995) Masculinities. Allen and Unwin, Sydney

Connell RW (2000) The men and the boys. Allen and Unwin; Polity Press; University of California Press, Sydney, Cambridge, Berkeley

Connell RW (2008) Southern theory: the global dynamics of knowledge in the social sciences. Polity, Cambridge, UK

Connell RW, Pearse R (2015) Gender: In World Perspective, 3rd edn, Polity Press, Cambridge, UK

Corbin J, Strauss A (2015) Basics of Qualitative Research. Techniques and Procedures for Developing Grounded Theory. Sage Publications, Inc, Thousand Oaks

Denzin NK (1989) Interpretive biography: qualitative research methods. Vol. 17 SAGE Publications, London, Newbury Park, New Delhi

Drudy S, Lynch K (1993) Schools and society in ireland. Gill and Macmillan, Dublin

Edwards T (2006) Cultures of masculinities. Routledge, New York, Oxford

Elmsäter M, Hétu S (2010) Human touch in education. The Massage in Schools Programme. http://www.misausa.com/wpcontent/uploads/2011/07/ massagearticle.pdf. Accessed 29 Apr 2016

Gilligan C (1982) In a different voice. Harvard University Press, London, Cambridge

Grosz E (2011) Becoming undone. Darwinian reflections onlife, politics, and art. Duke University Press, Durham, London

Goldberger N, Tarule J, Clinchy B, Belenky M (1996) Knowledge, difference, and power. essays inspired by women's ways of knowing. Basic Books, New York

Goldschmidt B, van Meines N (2012) Comforting touch in dementia and end of life care. Take My Hand. Singing Dragon, London and Philadelphia, PA

Gottfried H (2013) Gender, work, and economy: unpacking the global economy Polity, Cambridge

Hardy C, Prior K (2001) Attachment theory. In: Lougher L (ed) Occupational therapy for child and adolescent mental health. Churchill Livingstone, Edinburgh, London, New York pp 48-66

Haywood C, Mac an Ghaill M (2003) Men and masculinities: theory, research and social practice. Open University Press, Buckingham, Philadelphia

Haywood C, Mac an Ghaill M (2013) Education and masculinities: social, cultural and global transformations. Routledge, New York, NY

Hearn J, Morgan D (eds) (1990) Men, masculinities and social theory. Unwin Hyman, London

Hekman S (2005) Private selves, public identities: reconsidering identity politics. Philos Rev 25(1):29-31

Hesse-Biber SN, Leavy P (2011) The practice of qualitative research, 2nd edn. SAGE Publications, Thousand Oaks

Hochschild AR (2012) The managed heart: commercialization of human feeling University of California Press, Berkeley

InTouch (2014) Why the decline in male primary school teachers? Issue 148: 43 .

Jackson AY, Mazzei LA (2012) Thinking with theory in qualitative research viewing data across multiple perspectives. Routledge, London, New York

Jaggar AM (2008a) Love and knowledge: emotion in feminist epistemology. In Jaggar AM (ed) Just methods. An Interdisciplinary Feminist Reader. Paradigm Publishers, Boulder, London

Jaggar AM (ed) (2008b) Just methods. An Interdisciplinary feminist reader. Paradigm Publishers, Boulder, London

Jaggar A, Bordo SR (eds) (1992) Gender/Body/Knowledge. Feminist reconstructions of being and knowing. Rutgers University Press, New Brunswick, New Jersey

Kelan E (2009) Performing gender at work. Palgrave MacMillan, Hampshire

Kimmel M (2013) The gendered society, 5th edn. Oxford University Press, New York

King JR (1998) Uncommon caring: learning from men who teach young children. Teachers College Press, New York, Early Childhood Education Series

Lather P (1991) Getting smart: feminist research and pedagogy with/in the postmodern. Routledge, New York

Lather P (2009) Against empathy, voice and authenticity. In: Jackson AY, Mazzei LA (eds) Voice in Qualitative Inquiry. Challenging conventional, interpretive, and critical conceptions in qualitative research. Routledge, New York pp $17-26$ 
Lather P (2010) Engaging science. policy: from the side of the messy. Peter Lang Publications, Inc, New York

Lincoln TM, Wilhem K, Nestoriuc Y (2007) Effectiveness of psychoeducation for relapse, symptoms, knowledge, adherence and functioning in psychotic disorders: a metaanalysis. Schizophr Res 96:232-245

Lupton B (2000) Maintaining masculinity: men who do women's work. Br J Manag 11(S1):S33-S48

Lynch K (2013) Why love, care and solidarity are political matters: affective equality and Fraser's model of social justice. In: Jónadóttir A, Ferguson A (eds) Love: a question of feminism in the twenty-first century. Routledge, New York, pp 173-189

Mac an Ghaill M (1994) The Making of Men. Masculinities, Sexualities and Schooling. Open University Press, Buckingham

Martino W, Rezai-Rashti GM (2010) Male teacher shortage: black teachers' perspectives. Gend Educ 22(3):247-262

Mauthner NS, Doucet A (1998) Reflections on a voice centred relational method of data analysis: analysing maternal and domestic voices. In: Ribbons J, Edwards R (eds) Feminist Dilemmas in Qualitative Research: Private Lives and Public Texts. SAGE Publications, London, pp 119-144

McCracken G (1988) The long interview: qualitative research methods series 13. SAGE Publications, London, Newbury Park

Mirchandani K (2008) Challenging racial silences in studies of emotion work, in Greco and Stenner, emotions. A social reader. Routledge, London, New York, pp 264-275

Morgan W (2000) Electronic Tools for Dismantling the Master's House: Poststructuralist Feminist Research and Hypertext Poetics. In: St. Pierre EA, Pillow WS (eds) Working the ruins. Feminist poststructural theory and methods in education. Routledge, London, New York, pp 130-149

Noddings N (1992) The challenge to care in school. an alternative approach to education. Teachers College Press, London, New York

Nodding N (2006) The challenge to care in schools: an alternative approach to education, 2nd edn. Teachers College, Columbia University, New York

O'Keeffe S (2016) What are male teachers' understandings of masculinities?-an exploration of sex, gender and bodies in Irish primary schools. Palgrave Communications 2:16007. https://doi.org/10.1057/palcomms.2016.7

Pillow WS, Mayo C (2007) Toward understandings of feminist ethnography. In: HesseBiber SN (ed) Handbook of feminist research: theory and practice. SAGE Publications, London, New Delhi, Thousand Oaks, pp 155-171

Rapley T (2011) Some pragmatics of data analysis. In: Silverman D (ed) QualitativeResearch: Issues of Theory, Method and Practice, 3rd edn, SAGE Publications, London; Thousand Oaks, CA, pp 273-290

Reskin B (1991) Bring the men back in: sex differentiation and the devaluation of women's work. In: Lober J, Farrell S (eds) The social construction of gender. SAGE Publications, Beverly Hills pp 141-161

Skelton C (1996) Learning to be "Tough": The fostering of maleness in one primary school Gender and Education 8(2):185-197

Skelton C (2001) Schooling the boys: masculinities and primary education. Open University Press, Buckingham

Skelton C (2012) Men teachers and the feminised primary school: a review of the literature. Educ Rev 64(1):1-19

Spenser D, Walby K, Hunt A (eds) (2012) Emotions matter. a relational approach to emotions. University of Toronto Press, Toronto
Spradley JP (1979) The ethnographic interview. Holt, Rinehart and Winston, New York

Thornton M (1997) Gender issues in the recruitment, training and career prospects of early years and primary school teachers. Paper presented to the British Educational Research Association Conference. University of York, 11-14 September

Van Maanen J (2011) Tales of the Field: On Writing Ethnography, 2nd edn Chicago guides to writing, editing, and publishing. The Chicago University Press, Chicago, London

Walby S, Armstrong J, Strid S (2012) Intersectionality: multiple inequalities in social theory. Sociology 46(2):224-240. https://doi.org/10.1177/ 0038038511416164

Weaver-Hightower MB (2011) Male preservice teachers and discouragement from teaching. J Mens Stud 19(2):97-115

Wetterer A (2003) Rhetorische Modernisierung: Das Verschwinden der Ungleichheit aus dem zeitgenössischen Differenzwissen. as cited in Kelan E, Performing gender at work. Palgrave MacMillan, Hampshire

Whitehead S (2002) Men and masculinities. Polity, Cambridge

\section{Data availability}

The datasets generated during and/or analysed during the current study are not publicly available due to research ethics guideline restrictions but are available from the corresponding author on reasonable request.

\section{Additional information}

Competing interests: The author declares no competing interests.

Reprints and permission information is available online at http://www.nature.com/ reprints

Publisher's note: Springer Nature remains neutral with regard to jurisdictional claims in published maps and institutional affiliations.

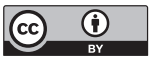

Open Access This article is licensed under a Creative Commons Attribution 4.0 International License, which permits use, sharing, adaptation, distribution and reproduction in any medium or format, as long as you give appropriate credit to the original author(s) and the source, provide a link to the Creative Commons license, and indicate if changes were made. The images or other third party material in this article are included in the article's Creative Commons license, unless indicated otherwise in a credit line to the material. If material is not included in the article's Creative Commons license and your intended use is not permitted by statutory regulation or exceeds the permitted use, you will need to obtain permission directly from the copyright holder. To view a copy of this license, visit http://creativecommons.org/ licenses/by/4.0/.

(c) The Author(s) 2018 